\title{
Kazimierz Bartoszyński w Poznaniu
}

ABSTRACT. Wysłouch Seweryna, Kazimierz Bartoszyński w Poznaniu [Kazimierz Bartoszyński in Poznań]. "Przestrzenie Teorii” 23. Poznań 2015, Adam Mickiewicz University Press, pp. 301309. ISBN 978-83-232-2920-9. ISSN 1644-6763. DOI 10.14746/pt.2015.23.22.

The author of this article discusses Kazimierz Bartoszyński's didactic activity and writings, i.e. his doctoral thesis titled O powieściach Fryderyka Skarbka [On Fryderyk Skarbek's Novels] (which was published in 1963) and his later articles on the gawęda (i.e. a story stylized as an oral tale) and historical novel (which are collected in the volume titled O polskich prozach powieściowych - słynnych i nieco zapomnianych [On Polish Prose Novels - Those Famous and Slightly Forgotten Ones] (2011)). These writings were a continuation of the studies of the $19^{\text {th }}$-century novel that had been conducted in Poznań.

Kazimierz Bartoszyński w Poznaniu pracował krótko, w latach 19541962, ale twierdzę, że był to okres decydujący w Jego biografii zawodowej, który zaważył na problematyce badań i warsztacie interpretacyjnym.

Jego kariera naukowa obfitowała w niezwykłe przypadki. Magisterium robił w Warszawie, u Wacława Borowego, ale 16 października 1950 roku, tuż przed egzaminem magisterskim, Borowy nagle zmarł. Wówczas opiekę nad pracą przejął Julian Krzyżanowski, który po raz pierwszy zetknąwszy się z kandydatem, nie wierzył, że praca jest samodzielna i zrobił mu przed egzaminem magisterskim klasówkę. Posadził Go w gabinecie i kazał pisać na zadany temat „wypracowanie”. Musiało ono wypaść przekonująco, bo adept nie tylko został dopuszczony do magisterium (w grudniu 1950), ale został aspirantem Instytutu Badań Literackich (1951). Cóż, kiedy w marksistowskim wówczas IBL-u przyczepiono mu łatkę „formalisty” i skazano na zsyłkę - do Poznania.

\section{Niezapomniana Bogunka na Gople}

Na Uniwersytecie Poznańskim (bo taką wówczas nazwę nosił dzisiejszy UAM) Bartoszyński wykładał romantyzm polski przed rokiem 1830 (dla II roku) i na III roku polonistyki prowadził ćwiczenia z podstawowego przedmiotu: historii literatury polskiej. Uczestniczyłam w tych zajęciach w roku akademickim 1960/1961. Nie wprowadzono jeszcze wtedy na polonistyce obowiązkowych prac rocznych, a mimo to Bartoszyński wymagał od wszystkich swoich studentów prac pisemnych. Czytał je i zwracał z merytoryczną recenzją. Nie znaczy to, że wcześniej nie pisa- 
liśmy referatów. Owszem, ale były one przeznaczone na zajęcia i na zajęciach czytane. Przygotowywali je z reguły „ochotnicy”, a że zajęć było mniej niż osób w grupie, zawsze część uczestników dostawała zaliczenia na podstawie obecności. Podobno byli nawet tacy, którzy przez całe studia nie napisali żadnej pracy... Ale żeby ktoś wymagał prac pisemnych i jeszcze w dodatku je czytał, to nie mieściło się w głowie. Kolega opowiadał ze śmiechem, jak to jeden z nich miał u „Bartola” kłopoty z zaliczeniem i pan magister kazał mu referat napisać na nowo. Kiedy zjawił się z przerobioną pracą, „Bartol” rzucił na nią okiem i podpisał mu indeks. Student, uszczęśliwiony, wychodząc, obejrzał się za siebie i zobaczył, że pan magister jego krwawicę zręcznym ruchem wrzucił do stojącego obok kosza...

Ćwiczenia z historii literatury prowadzone przez Bartoszyńskiego także zapadły mi w pamięć, bo ich problematyka była niezwykła. Otóż cały semestr analizowaliśmy mało znany, prozatorski utwór Ryszarda Berwińskiego Bogunka na Gople. Czy ktoś dzisiaj o nim pamięta? Każde ćwiczenie było poświęcone innemu problemowi, a te problemy to dziwaczny, pełen neologizmów język utworu, związki z balladą, z powieścią poetycką, folklor, kontekst słowianofilski i nie pamiętam, co tam jeszcze. Zajęcia miały charakter analityczny, a punktem wyjścia nie były dociekania genetyczne, tylko problemy teoretycznoliterackie: kategorie poetyki, genologia, tradycja literacka. Tak prowadzone ćwiczenia otwierały zupełnie inne perspektywy niż lektury Windakiewicza i Kleinera, w których się wówczas zaczytywałam. Miały także poważny mankament: cały semestr analizowaliśmy jeden niewielki, drugorzędny utwór, toteż jego tytuł szybko został przez wdzięcznych (i znudzonych) słuchaczy przerobiony na nieustającą Biegunkę na Gople...

Jak działalność dydaktyczna, tak i działalność naukowa Kazimierza Bartoszyńskiego była inna i osobna w środowisku poznańskim, gdzie królowała tradycyjna historia literatury. Patronowała jej wówczas tylko jedna literaturoznawcza katedra, do 1960 roku kierowana przez prof. Romana Pollaka, staropolanina (po jego odejściu na emeryturę przejął ją prof. Ziomek). Obok Pollaka autorytetem naukowym był wówczas w Poznaniu zasłużony badacz dziejów polskiej powieści, atakowany przez marksistów monografista twórczości Bolesława Prusa - prof. Zygmunt Szweykowski. I właśnie pod jego kierunkiem Kazimierz Bartoszyński napisał doktorat $O$ powieściach Fryderyka Skarbka, obroniony w pamiętnym roku 1960, kiedy to ministerstwo przywróciło stopnie doktorskie i kiedy mieliśmy niepowtarzalną okazję zobaczyć aż cztery publiczne obrony naszych asystentów [obronili wówczas doktoraty: Jarosław Maciejewski (w marcu), Tadeusz Witczak (w maju), Alojzy Sajkowski (w czerw- 
cu) i Kazimierz Bartoszyński (w grudniu)] ${ }^{1}$. Recenzentem Jego pracy był Henryk Markiewicz, a książka doktorska ukazała się w 1963 roku w prestiżowej serii IBL PAN, Historia i Teoria Literatury, wydawanej przez PIW i z powodu wyglądu okładki potocznie nazywanej „serią z jajkiem”.

\section{Strukturalista wśród genetyków}

Sądzę, że lata poznańskie i poznański doktorat zadecydowały o drodze naukowej Kazimierza Bartoszyńskiego. Książka $O$ powieściach Fryderyka Skarbka była nie tylko rewelacją w 1963 roku, ale zawierała wątki, które przez całe życie kontynuował oraz problemy teoretyczne, które z pasją rozwijał. Zaowocowała także pracami edytorskimi, jak przygotowanie nowych wydań dwóch powieści Skarbka: Pamiętników Seglasa (PIW, 1959) i Życia i przypadków Faustyna Feliksa na Dodoszach Dodosińskiego (PIW, 1959).

$\mathrm{Na}$ czym polegało nowatorstwo książki $O$ powieściach Fryderyka Skarbka? Przede wszystkim była to monografia, która zrywała z popularną formułą „życie i twórczość”. Jej kompozycją rządził rejestr zagadnień teoretycznych, wyprowadzonych ze stanu badań i wyszczególnionych w poświęconym recepcji rozdziale wstępnym. Znalazły się tam sternizm, powieść historyczna, problematyka narratora, gawęda, powieść sentymentalna, romans awanturniczy. Biografia autora stanowiła jedynie naszkicowane tło rozważań, natomiast głównym przedmiotem analiz stały się problemy narracji powieściowej i gatunki przedromantycznej powieści polskiej, korzystającej głównie ze wzorów Sterne’a, Scotta, Fieldinga. Analizując tę problematykę, Bartoszyński sięgał obficie do starych i nowych prac teoretycznych: Spielhagena, Scherera, Walzela, Friedemann, Stanzla, Mendilova, Lämmerta, Welleka i Warrena. Nikt przed Nim tak o prozie powieściowej nie pisał, koncentrowano się głównie na genezie utworów i na wątkach zapożyczonych. Tymczasem On analizował kategorię narratora, płaszczyznę narracji i problemy fikcji powieściowej w drugorzędnych powieściach Skarbka! I, co ciekawe, poszczególne rozdziały rozwijały kolejno te problemy bez zaburzenia chronologii utworów. Przyjęta metoda pracy pozwoliła Autorowi pokazać historycznoliterackie walory (i zapóźnienia) powieści Skarbka, widoczne w szeroko potraktowanym literackim kontekście, który tworzą dzieje polskich i europejskich

1 Zob. J. Maciejewski, Dzieje poznańskiej polonistyki uniwersyteckiej 1842-1988, Poznań 1992, s. 114. W roku 1960 odbyła się również habilitacja J. Maciejewskiego, który doktoryzował się i habilitował na podstawie wcześniej wydanych książek: Wielkopolskie opowiadania Henryka Sienkiewicza (1957) i Gdy gościt w Wielkopolszcze... (Adam Mickiewicz w Wielkim Księstwie Poznańskim 1831-1832) (1958). 
gatunków powieściowych (szczególnie powieść sternowska i walterscottowska). Jednym słowem Skarbek został usytuowany na mapie historycznoliterackich dziejów polskiej powieści. Bartoszyński akcentował przy tym problemy, które miały genezę Sterne’owską, ale współcześnie okazały się aktualne, jak powieść otwarta, ironia, fikcja literacka czy wyrazista kreacja płaszczyzny narracyjnej, podważająca mimesis. Dlatego Maria Żmigrodzka w recenzji książki Bartoszyńskiego mówi o dwóch trafnie połączonych autorskich perspektywach:

W zarysie monograficznym powieści Skarbka zostały więc szczęśliwie zrównoważone dwa punkty widzenia: perspektywa historyka, oceniającego znaczenie Skarbka dla dziejów rozwoju gatunku, i dwudziestowiecznego badacza, szukającego w zjawiskach literackiej przeszłości postaw artystycznych odpowiadających upodobaniom własnej epoki. I to jest jedną z ważkich przyczyn powodzenia autorskiego przedsięwzięcia ${ }^{2}$.

Nowoczesny warsztat analityczny pozwolił Bartoszyńskiemu zweryfikować wiele poglądów na temat powieści Skarbka. W swoich rozważaniach podkreślał integralność struktury utworu i starał się łączyć badania strukturalne $\mathrm{z}$ historią form powieściowych. Nie podejmował polemik metodologicznych expressis verbis ( $\mathrm{z}$ wyjątkiem krytyki metody Dibeliusa), toteż Żmigrodzka nazwała go „strukturalistą «umiarkowanym»"3.

Bartoszyński był pierwszym, który wykorzystując narzędzia teorii literatury, analizował narrację dawnej polskiej powieści. Później ukazała się (także w serii z jajkiem) rozprawa Marii Jasińskiej Narrator w powieści przedromantycznej 1776-1831 (1965), która szła tym samym tropem i w wielu miejscach korzystała z Jego ustaleń.

\section{I jak tu nie grać w ping-ponga...}

Kiedy Jego książka się ukazała, Bartoszyński nie pracował już w Poznaniu, wrócił do IBL-u. A jak to było, opowiadała prof. Czermińska. Z inicjatywy Kazimierza Budzyka (który stworzył Katedrę Teorii Literatury na Uniwersytecie Warszawskim i starał się wzbudzić zainteresowania teoretyczne polonistycznej młodzieży) powstał cykl corocznych, tygodniowych konferencji teoretycznoliterackich (kontynuowanych do dziś), przeznaczonych początkowo dla młodych adeptów nauki. Pierwsza taka konferencja, zorganizowana przez UW, miała miejsce w Rogowie 7-12 lu-

2 M. Żmigrodzka, Narrator $w$ powieści przedromantycznej 1776-1831, „Pamiętnik Literacki" 1965, z. 3, s. 234.

3 Tamże, s. 235. 


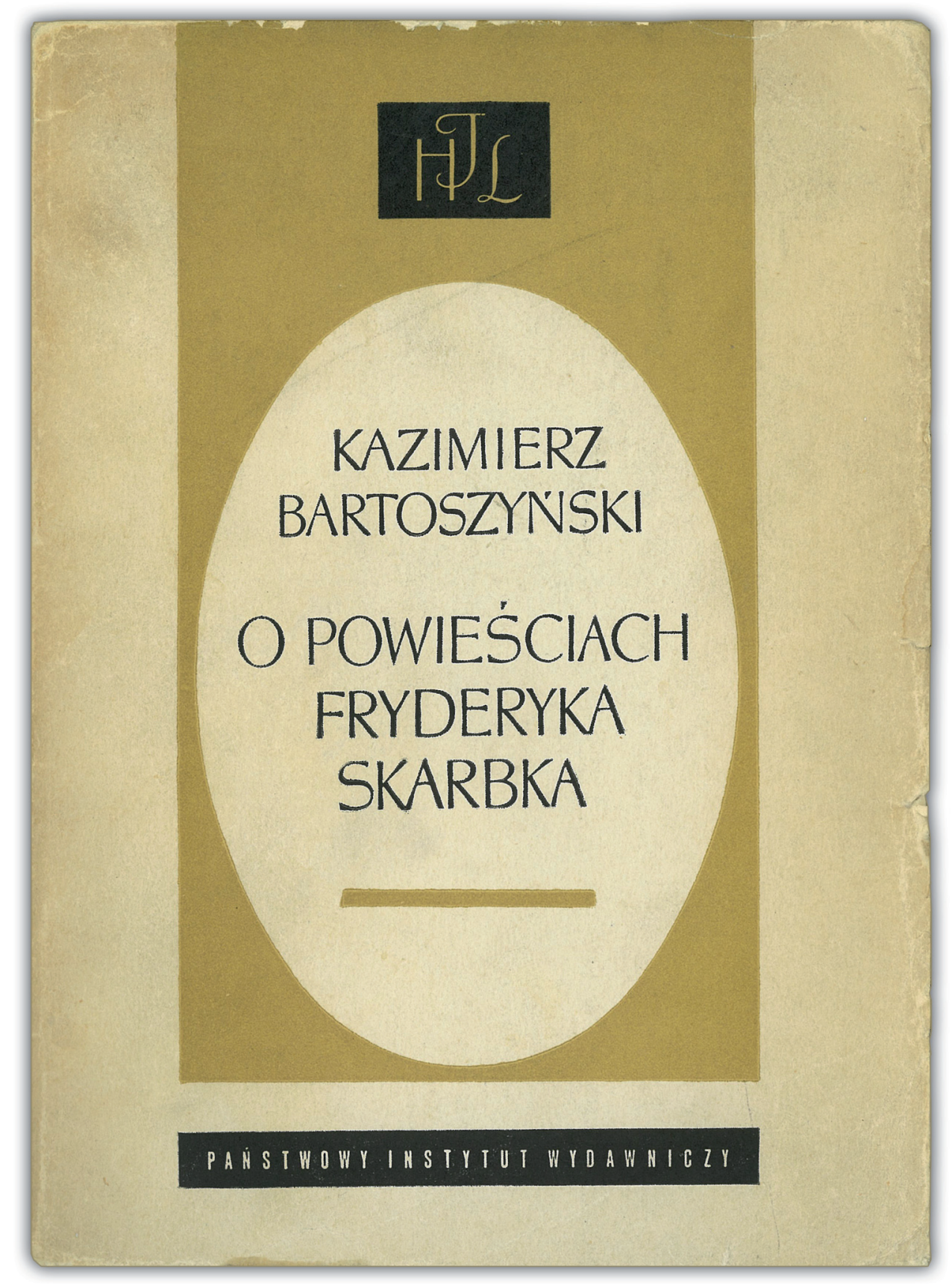

Kazimierz Bartoszyński, O powieściach Fryderyka Skarbka, Seria Historia i Teoria Literatury, PIW, Warszawa 1963, ss. 303. 


\section{Kazimierz}

\section{Bartoszyński}


tego 1962. Wygłoszono na niej 15 referatów o bardzo różnej problematyce, jednakże połowa $\mathrm{z}$ nich dotyczyła dziejów polskiej prozy ${ }^{4}$. Bartoszyńskiego nie ma wśród referentów, ale ze względu na przygotowanie merytoryczne i skłonność do nieustannych dywagacji był zapewne najgorliwszym z dyskutantów. Bo dyskutantem był niezrównanym. Miał niesłychaną łatwość syntetyzowania problemów, wszystko potrafił uporządkować logicznie i celnie podsumować. Musiał zwrócić na siebie uwagę organizatorów. Otóż któregoś konferencyjnego wieczora grał w ping-ponga z profesorem Budzykiem i między jednym odbiciem piłeczki a drugim prof. Budzyk zaproponował mu pracę w IBL-u, w Pracowni Dziejów Form Artystycznych w Literaturze Polskiej, którą organizował. I tak oto ping-pong przesądził, że Kazimierz Bartoszyński wrócił z poznańskiej zsyłki i od kwietnia 1962 do emerytury w 1991 roku był kolejno adiunktem, docentem (1968) i profesorem (1987) w Instytucie Badań Literackich PAN w Warszawie. Tam znalazł grono przyjaciół i uczestniczył w najciekawszym okresie istnienia IBL-u - w czasie burzliwych dyskusji, przemian metodologicznych i ożywienia kontaktów z Zachodem. Janusz Sławiński nazwał lata sześćdziesiąte złotymi latami IBL-u, ponieważ „w jednym miejscu i czasie spotkały się nader różnorodne tradycje myśli literaturoznawczej, różne szkoły naukowe, różne pokolenia badaczy, a wśród nich - wyjątkowo zróżnicowane indywidualności i temperamenty"5. Jednak pracując w IBL-u, Bartoszyński związków z Poznaniem nie zerwał. Czekając na mieszkanie spółdzielcze w stolicy, jeszcze przez kilka lat przemieszkiwał w hotelu asystenckim w Poznaniu, kursując między Warszawą i Łańcutem.

\section{Powroty i kontynuacje}

Studia nad prozą Skarbka miały w biografii Autora powroty i ciągi dalsze. Rozdział o Pamiętnikach Seglasa, w którym udowodnił, że dzieło to - napisane $\mathrm{w}$ czasie wielkiej popularności i jednocześnie banalizacji narracji gawędowej - ukształtowane jest jako antygawęda, został po latach przypomniany. Znalazł się w ostatnim tomie Jego interpretacji, wydanym pod tytułem $O$ polskich prozach powieściowych - slynnych i nieco zapomnianych (2011). Skarbek - jako ekonomista - zaistniał również

${ }^{4}$ Zob. I. Opacki, Ogólnopolska konferencja teoretycznoliteracka pomocniczych pracowników naukowych 7-12 lutego 1962, „Pamiętnik Literacki” 1962, z. 2; J. Sławiński, Wprowadzenie do badań nad konferencjami teoretycznoliterackimi, [w:] Teoretycznoliterackie tematy i problemy, red. J. Sławiński, Wrocław 1986.

5 J. Sławiński, IBL od przedwczoraj do jutra. Rozmawiam z „Kultura Niezależna”, [w:] tenże, Teksty i teksty, Warszawa 1990, s. 231. 
w numerze „Tekstów Drugich”, poświęconych „Ekonomii po literacku” w artykule Ekonomia - historia - literatura. Na marginesie twórczości Fryderyka Skarbka ${ }^{6}$.

Jednak ważniejsze niż „powroty Skarbka” są w moim przekonaniu kontynuacje fundamentalnych problemów omawianych w tej „poznańskiej” monografii: gawędy i powieści historycznej.

Otóż znakomity artykuł $O$ amorfizmie gawędy. Uwagi na marginesie „Pamiątek Soplicy” ma poznańską genezę. Napisany został dla uczczenia 70-lecia prof. Szweykowskiego i opublikowany w ofiarowanym mu przez grono uczniów i współpracowników tomie Prace o literaturze $i$ teatrze (1966) ${ }^{7}$. Wśród prac tam zamieszczonych artykuł Bartoszyńskiego miał pozycję szczególną: dotyczył Pamiątek Soplicy Henryka Rzewuskiego, któremu prof. Szweykowski niegdyś poświęcił monografię Powieści historyczne Henryka Rzewuskiego (1922), a Pamiatki Soplicy opracował w serii Biblioteki Narodowej (1928). Bartoszyński zaprezentował się więc jako kontynuator swojego promotora i jednocześnie jako innowator. Zanalizował bowiem elementy dotąd w analizach pomijane: konstrukcję czasu, informacyjność tekstu (wprowadzając delikatnie kategorię redundancji) i pozycję odbiorcy. Pokazał, że gawęda była gatunkiem opozycyjnym wobec „klasycznej” powieści dziewiętnastowiecznej i, co najciekawsze, zwrócił uwagę na trend rozwojowy powieści XX wieku, która również $\mathrm{w}$ analogicznych punktach - szczególnie w swojej odmianie psychologicznej - odchodzi od formy „klasycznej”. Tym samym bardzo ostrożnie zarysował daleką paralelę między gawędą a powieścią psychologiczną XX wieku. Mimo ostrożności i zastrzeżeń autora taka metoda postępowania musiała w Poznaniu w latach sześćdziesiątych szokować. Wiele lat później słyszałam, jak przy jakiejś okazji prof. Maciejewski (który bardzo lubił przypinać strukturalistom łatki) ironicznie powiedział, że „strukturaliści z Pcimia"8 łączą gawędę z powieściami Virginii Woolf... Widać praca Bartoszyńskiego zapadła mu w pamięć bardzo głęboko.

Gawędowy problem pojawił się raz jeszcze, w artykule $O$ polskiej literaturze „zaprzecznej”. Uwagi o twórczości Henryka Rzewuskiego i Andrzeja Kuśniewicza (2010) ${ }^{9}$. Tam jednak prof. Maciejewski nie mógłby się przyczepić, bo chodziło o wyraźne nawiązania intertekstualne, obecne w powieści Kuśniewicza i o polemikę z tradycją.

${ }^{6}$ K. Bartoszyński, Ekonomia - historia - literatura. Na marginesie twórczości Fryderyka Skarbka, „Teksty Drugie” 1991, nr 5, s. 25-44.

${ }^{7}$ Prace o literaturze i teatrze ofiarowane Zygmuntowi Szweykowskiemu, red. J. Maciejewski, Wrocław 1966.

8 W Pcimiu odbyła się konferencja teoretycznoliteracka w 1965 roku.

9 K. Bartoszyński, O polskiej literaturze „zaprzecznej”. Uwagi o twórczości Henryka Rzewuskiego i Andrzeja Kuśniewicza, „Pamiętnik Literacki” 2010, z. 3. 
Za „poznańskie” uważam także prace o powieści historycznej: „Popioty” $i$ kryzys powieści historycznej (1965) oraz jej późniejszą kontynuację O poetyce powieści historycznej (1984)10. Wynikają one z przemyśleń na temat popularnego gatunku, omawianego już w monografii twórczości Skarbka. Tekst „Popioły” i kryzys powieści historycznej został napisany w stulecie urodzin Żeromskiego i opublikowany w „Pamiętniku Literackim" z 1965 roku, w bloku materiałów rocznicowych ${ }^{11}$, obok - między innymi - artykułu Artura Hutnikiewicza Problematyka form kompozycyjnych $w$ sztuce pisarskiej Żeromskiego oraz artykułu Michała Głowińskiego, Anachronizm i konstrukcja czasu (Z problemów poetyki Żeromskiego). Referat Hutnikiewicza był wygłoszony na zorganizowanej w IBL-u sesji i wywołał burzliwą dyskusjęㄹ, ponieważ autor - monografista Żeromskiego - postawił ostro tezę (znaną z jego wcześniejszych publikacji) o złej kompozycji utworów Żeromskiego, co według niego wynikało z niewydolności wyobraźni, bezradności wobec materii literackiej i niedowładu sztuki pisarskiej. Na sesji polemizowali z tym stanowiskiem Wacław Kubacki, Stanisław Frybes i Henryk Markiewicz. Wysuwali różne argumenty: może kompozycja nie jest zła, tylko nietradycyjna? (Kubacki). Według Frybesa kompozycja świadczy o przełomie modernistycznym, ponieważ jest taka sama u Struga, Berenta, Irzykowskiego. Według Markiewicza natomiast Żeromski nie jest ani nieudolnym tradycjonalistą, ani genialnym nowatorem, tylko pisarzem przełomu. Jednak żaden z dyskutantów Hutnikiewicza nie przekonał. I oto problem kompozycji utworów Żeromskiego został rozwiązany w opublikowanych kilka miesięcy później w „Pamiętniku Literackim” artykułach IBL-owców, Bartoszyńskiego i Głowińskiego, którzy precyzyjnie zanalizowali poetykę autora Ludzi bezdomnych.

Praca Bartoszyńskiego „Popioły” i kryzys powieści historycznej miała znaczenie fundamentalne. Pierwsza jej część poświęcona została kompetentnie scharakteryzowanej poetyce powieści historycznej, w wersji Sienkiewiczowskiej. Na tle tej konwencji zostały ukazane Popioły jako powieść opozycyjna wobec tradycji gatunku. Nieciągłość świata przedstawionego, addytywność fabuły, desubstancjalizacja postaci, personalny punkt widzenia narratora i związana z tym niejednorodność narracji, wreszcie elementy modernistyczne (szczególnie w przedstawianiu życia

10 „Pamiętnik Literacki” 1984, z. 2. Przerobiona i poszerzona wersja tej pracy weszła do zbioru K. Bartoszyńskiego Powieść w świecie literackości, Warszawa 1991. 1965, z. 1.

11 K. Bartoszyński, „Popioły” $i$ kryzys powieści historycznej, „Pamiętnik Literacki”

12 Zob. A. Piorunowa, Stefan Żeromski (14 X 1864-20 XI 1925). Sprawozdanie z konferencji naukowej Instytutu Badań Literackich PAN, „Pamiętnik Literacki” 1965, z. 1, s. 333-336. 
wewnętrznego postaci) - uaktywniają według Bartoszyńskiego rozwiązywane dotąd kompromisowo antynomie powieści historycznej i rozbijają dziewiętnastowieczną konwencję. Bartoszyński nie polemizuje wprost z poglądami Hutnikiewicza, ale używając form nieosobowych, trybu warunkowego i metatekstu delikatnie zwraca uwagę na przyjęte przez niego niewłaściwe kryteria wartościowania:

Mówiąc o rozbiciu w Popiołach spoistości poetyki tradycyjnej powieści historycznej, należałoby w konsekwencji unikać - co nie zawsze jest przestrzegane [tu przypis do Borowego i Hutnikiewicza - S.W.] - odnoszenia tego dzieła do owej poetyki jako do systemu kryteriów oceny ${ }^{13}$.

Wypowiedź ta charakteryzuje Bartoszyńskiego doskonale. Był niezrównanym dyskutantem, ale bardzo ostrożnym polemistą. Nie wyostrzał kontrowersji, raczej je retorycznie zamazywał i osłabiał.

Inaczej Michał Głowiński. Jego artykuł Anachronizm i konstrukcja czasu (Z problemów poetyki Żeromskiego) ma charakter polemiczny. Głowiński problem wartościowania prozy Żeromskiego stawia w centrum i na wstępie zadaje pytanie, czy słusznie ocenia się ją według kryteriów klasycznej powieści realistycznej XIX wieku? Dokładna analiza konstrukcji czasu, postawy narratora, stosunku do czasu historycznego i jej konsekwencje $\mathrm{w}$ zakresie budowy fabuły i postaci pokazują odejście od poetyki realistycznej, które Głowiński wiąże z wczesną fazą ekspresjonizmu. W ten sposób analiza warsztatu pisarza dokonana w obrębie różnych gatunków - powieści historycznej i powieści klasycznego realizmu - udowodniła odmienność poetyki Żeromskiego od kryteriów dziewiętnastowiecznych, które nie powinny być podstawą artystycznej oceny. Ale Artur Hutnikiewicz w kwestii złej kompozycji powieści Żeromskiego $\mathrm{i}$ tak nie zmienił zdania14. Jednakowoż umieszczenie $\mathrm{w}$ jednym numerze „Pamiętnika Literackiego” artykułu Hutnikiewicza obok artykułów IBL-owców miało swoją wymowę, zapraszało do konfrontacji. Świadczyło o dalszym ciągu rozpoczętej na sesji „monachomachii literackiej” tudzież o konflikcie strukturalistów z genetykami, który wyraźnie zarysował się nieco później - na konferencji „Proces historyczny w literaturze i sztuce"15.

${ }^{13}$ K. Bartoszyński, „Popioły” $i$ kryzys powieści historycznej, s. 100.

14 Zob. A. Hutnikiewicz, Żeromski, Warszawa 2000 (rozdz. Budowa i kompozycja). Prace Bartoszyńskiego i Głowińskiego nie zostały uznane za ważne i autor je pominął w bibliografii.

15 Zob. dyskusję nad referatem J. Sławińskiego Synchronia $i$ diachronia $w$ procesie historycznoliterackim, zamieszczoną $\mathrm{w}$ tomie zbiorowym Proces historyczny $w$ literaturze $i$ sztuce, red. M. Janion, A. Piorunowa, Warszawa 1967. 
Okres poznański w badaniach Kazimierza Bartoszyńskiego to prace nad dziejami polskiej powieści i znakomite analizy warsztatowe gatunków prozatorskich, takich jak powieść historyczna, sterne'owska czy gawęda, które później - jak starałam się pokazać - były przez Niego kontynuowane. Wszystkie swoje „teksty o tekstach”, o których tu pisałam, Autor zebrał w tomie $O$ polskich prozach powieściowych - stynnych $i$ nieco zapomnianych (2011). Znaczenie tego tomu dla badaczy polskiej prozy jest nie do przecenienia.

Przełom lat sześćdziesiątych i siedemdziesiątych XX wieku to już okres warszawski, lata świetności IBL-u i ożywienia życia naukowego. Bartoszyński był w jego centrum, tam skrystalizowały się Jego zainteresowania. Zajął się problematyką czysto teoretyczną: filozofią i kondycją powieści, studiami nad kategorią czasu, teorią Ingardena, komunikacją literacką. Obok Skarbka i Rzewuskiego na Jego warsztacie interpretacyjnym pojawił się Gombrowicz. Ale to już inna historia. 